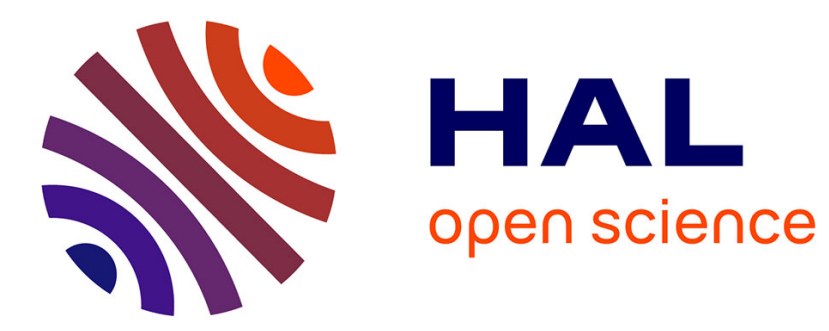

\title{
N- and Al-K-Edge EXAFS of AIN Grown on GaAs by MBE
}

\author{
M. Katsikini, E. Paloura, E. Holub-Krappe, T. Cheng, C. Foxon
}

\section{To cite this version:}

M. Katsikini, E. Paloura, E. Holub-Krappe, T. Cheng, C. Foxon. N- and Al-K-Edge EXAFS of AIN Grown on GaAs by MBE. Journal de Physique IV Proceedings, 1997, 7 (C2), pp.C2-1127-C2-1128. 10.1051/jp4:19972156 . jpa-00255219

\section{HAL Id: jpa-00255219 https://hal.science/jpa-00255219}

Submitted on 1 Jan 1997

HAL is a multi-disciplinary open access archive for the deposit and dissemination of scientific research documents, whether they are published or not. The documents may come from teaching and research institutions in France or abroad, or from public or private research centers.
L'archive ouverte pluridisciplinaire HAL, est destinée au dépôt et à la diffusion de documents scientifiques de niveau recherche, publiés ou non, émanant des établissements d'enseignement et de recherche français ou étrangers, des laboratoires publics ou privés. 


\title{
N- and Al-K-Edge EXAFS of AIN Grown on GaAs by MBE
}

\author{
M. Katsikini****, E.C. Paloura**,(1) , E. Holub-Krappe ${ }^{* *}$, T.S. Cheng*** and C.T. Foxon ${ }^{* * *}$ \\ * Aristotle University of Thessaloniki, Department of Physics, 54006 Thessaloniki, Greece \\ ** Hahn-Meitner Institute (A.S.), Glienicker Str. 100, 14109 Berlin, Germany \\ *** University of Nottingham, Department of Physics, NG7 2RD, UK
}

\begin{abstract}
Hexagonal AlN, epitaxially grown on GaAs, is studied with $\mathrm{X}$-ray absorption measurements at the $\mathrm{N}$ and Al-K-edges. The measured nearest neighbour (nn) distances are found shorter than expected by $0.04 \AA$ to $0.13 \AA$ for the $I^{\text {st }}$ to $3^{\text {rd }} \mathrm{nn}$ shells, respectively, while there is no evidence of undercoordination for the $\mathrm{N}$ or $\mathrm{AI}$ atoms. The reduction in the $\mathrm{nn}$ distances is attributed to the presence of oxygen contamination. The characteristic angular dependence of the N-K-edge NEXAFS spectra verifies the hexagonal structure of the AlN film while the $\mathrm{N}-\mathrm{Al}-\mathrm{N}$ bond angle, determined from the angular dependence of the NEXAFS spectra, is found equal to $53.8 \pm 5.7^{\circ}$ indicating that the oxygen does not distort significantly the local symmetry around the $\mathrm{N}$ atom.
\end{abstract}

\section{Introduction}

AlN has some attractive physical properties, such as high hardness and thermal conductivity, which render it suitable for applications in microelectronics. The current emphasis in AIN research stems primarily from the properties of its alloys with GaN which permit bandgap engineering and the fabrication of AlGaN based optical devices active in the blue and UV [1]. The main problems in AlN technology are related to the reactivity of $\mathrm{Al}$ and more specifically to the formation of $\mathrm{AlN}_{\mathrm{x}} \mathrm{O}_{\mathrm{y}}$ compounds. The $O$-related defect, which consists of an $O_{\mathrm{N}}$ and a $\mathrm{V}_{\mathrm{Al}}$ created at a ratio $\mathrm{O}_{\mathrm{N}} / \mathrm{V}_{\mathrm{Al}}=3$, is reported to cause a reduction of the lattice parameters [2].

Here we present an EXAFS study, at the N-, Al- and O-K-edges, of AlN grown on SI (001) GaAs in a molecular beam epitaxy system equipped with an if activated plasma source. The AlN film was grown at $650^{\circ} \mathrm{C}$ and is $1 \mu \mathrm{m}$ thick. The AIN surface was protected against oxidation by an in-situ deposited 7nm thick GaN layer. The X-ray absorption data revealed that the GaN cap is not providing sufficient protection against $\mathrm{Al}$ oxidation and from a comparison of the $\mathrm{N}$ and $\mathrm{O}$ edge jumps it is estimated that the $\mathrm{O}$ concentration amounts to nearly $20 \%$ of the $\mathrm{N}$ concentration. The EXAFS spectra were recorded at the $\mathrm{N}$ - and Al-K-edges, using the SX-700-I plane grating monochromator at the electron storage ring BESSY in Berlin. Detection was in the fluorescence mode (angle of incidence $35^{\circ}$ ), using a high purity Ge detector. The data recording system permitted simultaneous recording of two energy windows at the $\mathrm{N}$ - and $\mathrm{O}-\mathrm{K}$-edges and thus the two edges could be electronically isolated [3]. The angle-resolved N-K-edge NEXAFS measurements were recorded for five values of the angle of incidence $\vartheta, 20^{\circ} \leq 9 \leq 80^{\circ}$, where $\vartheta$ is measured with respect to the sample surface.

\section{Results and Discussion}

The EXAFS analysis at the N-K-edge was done with EXCURV90 [4] assuming a hexagonal AlN model. The data were fitted by iterations for the nearest neighbour $(\mathrm{nn})$ distances $\left(\mathrm{R}_{\mathrm{i}}\right)$ and coordination numbers $\left(\mathrm{N}_{\mathrm{i}}\right)$ over the 6 nn shells, consisting of $\mathrm{Al}$ and $\mathrm{N}$ atoms, alternatively. The Debye-Waller factors $\left(\sigma^{2}\right)$ were determined from the correlated Debye model. The background subtraction induced error was determined by analysis with different spline functions. The results from the EXAFS analysis for the nn distances and coordination numbers for the well separated $3 \mathrm{nn}$ shells are listed in Table 1. The $\chi(\mathrm{k})$ versus $\mathbf{k}$ spectrum from the N-K-edge and the corresponding Fourier transform (FT) are shown in Fig.1. The data shown in the figure have not been subjected to Fourier filtering and the FT has been calculated in the k-range 4.3-10 $\AA^{-1}$. Attempts to include $\mathrm{N}-\mathrm{O}$ paths have not improved the fitting. The $\mathrm{N}-\mathrm{Al}$ distance is found to be $1.85 \AA$ which is smaller by $0.04 \AA$ from the value predicted by the AlN model. This distance reduction could be attributed to the O-defect which results in a contraction of the unit cell [2]. The coordination of the $\mathrm{N}$ atom is tetrahedral, as expected from the hexagonal AlN model.

${ }^{(1)}$ On leave from: Aristotle University of Thessaloniki, Department of Physics 54006 Thessaloniki, Greece. 
The Al- EXAFS spectra were analysed with the FEFF code (FEFFIT 3.23) [5] over the k-range 4.8-9.6 $\AA^{-1}$ while the $O$-edge was analysed with both EXCURV and FEFFIT, which gave identical results. The measured $N_{i}$ and $R_{i}$ at the Al-K-edge are also listed in Table 1 while the $\chi(\mathrm{k})$ spectra and the FT are shown in Fig.2. At the Al-K-edge the iteration was done for the $4 \mathrm{nn}$ shells (fixed $\mathrm{Al}-\mathrm{N}$ and $\mathrm{Al}-\mathrm{O}$ distances to the values derived from the $\mathrm{N}$ - and $\mathrm{O}-\mathrm{K}$-edges respectively and fixed total coordination numbers in the $1^{\text {st }}$ and $2^{\text {nd }} \mathrm{nn}$ shells) while at the $\mathrm{O}$ edge only the Al nn was included. The effective coordination of the $\mathrm{Al}$ atom in the 1 st $\mathrm{nn}$ shell is 4.1 ("subshells" consisting of $\mathrm{O}$ and $\mathrm{N}$ atoms) and that of the $2^{\text {nd }}$ nn shell is 11.2 ("subshells" consisting of $\mathrm{Al}$ atoms bonded to $\mathrm{N}$ and $\mathrm{Al}^{\prime}$ atoms bonded to $\mathrm{O}$ ). The EXAFS results from the $\mathrm{O}-\mathrm{K}$-edge show that $\mathrm{O}$ has $2.5 \mathrm{Al}$ atoms as $\mathrm{nn}$ at a distance of $1.67 \mathrm{~A}\left(\sigma_{\mathrm{i}}{ }^{2}=0,005\right)$. The fact that $\mathrm{O}$ is bonded only to $\mathrm{Al}$ was verified by a comparison of the envelope functions for the 1st $\mathrm{nn}$ shells using $\mathrm{Al}_{2} \mathrm{O}_{3}$ and $\mathrm{NO}_{2}$ models. As shown in the Table, the distances affected strongly by the presence of $\mathrm{O}$ are those involving bonded $\mathrm{O}$ while the Al-N-Al tin distance is not affected significantly.

The angular dependent NEXAFS measurements were analysed as reported previously [6]. The energy position and full width at half maximum of the NEXAFS resonances do not depend on $\vartheta$ and this is a characteristic property of a crystal with hexagonal $\left(\mathrm{C}_{6 \mathrm{v}}\right)$ symmetry. From the angular dependence of the resonance intensities the Al-N-Al bond angles were found equal to $53.8 \pm 5.7^{\circ}$.

Table 1 : EXAFS analysis results from the $\mathrm{N}$ - and $\mathrm{Al}-\mathrm{K}$-edges. The $3 \mathrm{rd}$ m of the absorbing $\mathrm{Al}$ atom $\left(\mathrm{Al}^{\prime}\right.$ ) is bonded to $\mathrm{O}$. The values shown in parenthesis correspond to the hexagonal AlN model.

\begin{tabular}{|c|c|c|c|c|c|c|c|c|}
\hline \multicolumn{5}{|c|}{ N-K-edge } & \multicolumn{4}{|c|}{ Al-K-edge } \\
\hline shell \# & $\mathbf{N}_{\mathbf{i}}$ & atom & $\mathbf{R}_{\mathbf{1}}$ & $\sigma_{i}^{2}\left(\AA^{2}\right)$ & $\mathbf{N}_{i}$ & atom & $\mathbf{R}_{\mathbf{i}}$ & $\sigma_{i}^{2}\left(\AA^{2}\right)$ \\
\hline 1 & $4,3 \pm 0.4(4)$ & $\mathrm{Al}$ & $1,85 \pm 0,01(1.89)$ & 0,009 & $1,2 \pm 0.1$ & $\mathrm{O}$ & $1,67 \pm 0,01$ & 0,011 \\
\hline 2 & $12,1+2.0(12)$ & $\mathrm{N}$ & $3,02 \pm 0,02(3,09)$ & 0,013 & $2,9 \pm 0.3$ & $N$ & $1,84 \pm 0,01$ & 0,015 \\
\hline 3 & $9,7 \pm 2.5(10)$ & $\mathrm{Al}$ & $3,52 \pm 0,03(3,65)$ & 0,014 & $3,7 \pm 0.8$ & $\mathrm{Al}^{\prime}$ & $2,53 \pm 0,02$ & 0,015 \\
\hline & & & & & $7,5 \pm 1.5$ & Al & $2,84 \pm 0,02$ & 0,016 \\
\hline
\end{tabular}

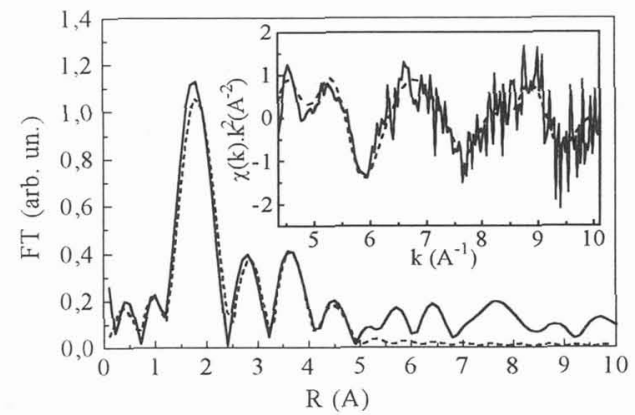

Fig. 1 : FT and $\chi(k)-k$ spectrum from the N-K-edge

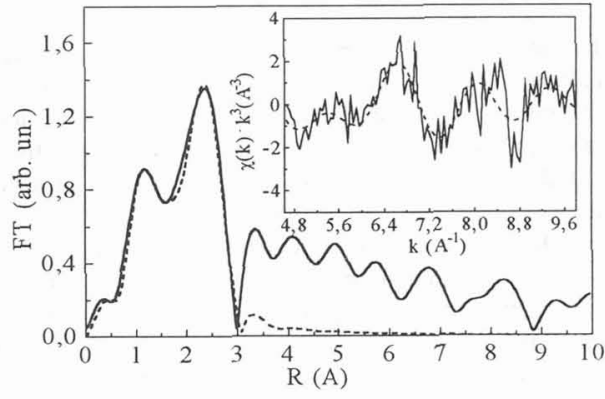

Fig. 2 : FT and $\chi(\mathrm{k})$ - $\mathrm{k}$ spectrum from the Al-K-edge

\section{Conclusions}

The EXAFS measurements at the $\mathrm{N}$ - Al- and $\mathrm{O}-\mathrm{K}$-edges reveal that in the presence of $\mathrm{O}$-contamination the nn distances in $\mathrm{AlN}$ are reduced, in accordance with previously reported $\mathrm{XRD}$ results, while the effect of $\mathrm{O}$ is stronger around the $\mathrm{Al}$ atom with which it is preferentially bonded. The $\mathrm{Al}-\mathrm{N}-\mathrm{Al}$ bond angle, determined from the angular dependence of the $\mathrm{N}-$ NEXAFS spectra, is found equal to $53.8 \pm 5.7^{\circ}$. This value agrees well with that determined from XRD measurements [7] and indicates that the local symmetry around the $\mathrm{N}$-atom, as determined by the no distance and the bond angle, is not significantly distorted by the presence of oxygen.

Acknowledgements : Financial support from the EC-HCM (CHGE-CT93-0027) program is gratefully acknowledged.

\section{References}

[1]. S. Nakamura, T. Mukai and M. Senoh, Appl. Phys. Lett. 64, 1687, 1994

[2]. A. Slack, J. Phys. Chem. Solids, 34, 321 (1973).

[3]. L. Tröger, T. Yokoyama. D. Arvanitis, T. Lederer, M. Tischer and K. Baberschke, Phys. Rev. B49, 888 (1994),

[4]. S. J. Gurman, N. Binsted and I. Ross, J. Phys. C 17, 143 (1984).

[5]. J. Mustre de Leou, J. J. Rehr, R. C. Albers, S. I. Zabinsky, Phys. Rev. B44, 3937 (1992).

[6]. M. Katsikini, E. C. Paloura, J. Kalomiros, P. Bressler, T. D. Moustakas, Proceedings, $23^{d}$ ICPS (in press).

[7]. G. A. Jeffrey, G. S. Parry, R. L. Mozzi, J. Chem. Phys. 25, 1024 (1955) 